3 Berry FA Jr, Yarborough S, Yarborough N, Russell CM, Carpenter MA, Hendley JO. Transient bacteremia during dental manipulation in children. Pediatrics 1973;51:476-9.

4 Shanson DC, Thomas F, Wilson D. Effect of volume of blood cultured on detection of Streptococcus viridans bacteraemia. 7 Clin Pathol 1984;37:568-79.

5 Newsom SWB. Antibiotic prophylaxis for open-heart surgery. F Antimicrob Chemother 1978:4 389-91.

Accepted 7 August 1985

Departments of Anaesthetics and Microbiology, Mater Misericordiae Hospital, Dublin 7, Ireland

A J MCSHANE, MRCPI, FFARCSI, senior registrar in anaesthesia

R HONE, MD, consultant microbiologist

Correspondence and requests for reprints to: Dr A J McShane, Department of Anesthesiology and Critical Care Medicine, Johns Hopkins Hospital, Baltimore, Maryland 21205, USA

\section{Effect of knowledge of serum enzyme concentrations on doctors' interpretation of electrocardiographic manifestations in suspected acute myocardial infarction}

While collecting data from a patient clinicians form an idea of a diagnosis, and this idea may influence their interpretation of further observations in the patient. We conducted a randomised study to determine whether doctors were influenced by their knowledge of changes in serum enzyme concentrations when interpreting electrocardiographic manifestations in patients suspected of having acute myocardial infarction.

\section{Patients, methods, and results}

In a consecutive series of 215 patients ( 71 women) with suspected acute myocardial infarction serum enzyme concentrations (glutamic oxaloacetic transaminase and lactate dehydrogenase) were determined, and a 12 lead electrocardiogram was recorded daily during the first three days after admission.

Two specialists in cardiology (A,B), two specialists in internal medicine (C,D), and two physicians with six and 10 months' clinical training in internal medicine $(\mathrm{E}, \mathrm{F})$, independently recorded whether changes in serum enzyme concentration were suggestive of acute myocardial infarction (positive) or not (negative). The patients were then randomised into two groups, and the doctors independently recorded whether the electrocardiographic manifestations were suggestive of acute myocardial infarction (positive) or not (negative). In group 1 the doctors interpreted the electrocardiograms with knowledge of the enzyme concentration and their previous interpretations of these, whereas in group 2 the electrocardiograms were interpreted without this knowledge.

For each observer the overall agreements between his interpretations of the electrocardiograms and his interpretation of the enzyme concentrations in both groups of patients were compared by Fisher's exact test (two sided). Patients in both groups whose enzyme concentrations had been interpreted as suggesting infarction were identified (group 1, positive; group 2, positive), and the frequency of concordant interpretations of enzyme concentrations and the electrocardiogram in the two subgroups was compared with Fisher's c...ict test (two sided). Patients whose enzyme concentrations had not suggested infarction group 1, negative; group 2, negative) were compared in the same way.

For all six doctors the overall agreement between the interpretations of enzyme concentrations and of electrocardiograms was higher in group 1 than group 2 . For one specialist $(\mathrm{A})$ and one trainee $(\mathrm{E})$ in internal medicine this difference was significant $(\mathrm{p}<0.05)$. The level of agreement achieved by all six doctors in patients whose enzyme concentrations had suggested acute myocardial infarction (groups 1 and 2, positive) was higher in group 1 than group 2 (table); for four doctors $(A, C, D, E)$ this difference was significant $(p<0.01)$. No significant difference in the level of agreement was found between the two groups for those patients whose enzyme concentrations had not suggested acute myocardial infarction (groups 1 and 2, negative)

\section{Comment}

Hanson described the influence of prior knowledge on the interpretation of observations, ${ }^{1}$ and Johnson emphasised the importance of this in diagnostic decision making. ${ }^{2}$ Gynaecologists have been shown to be influenced by their knowledge of the duration of amenorrhoea when estimating the size of the uterus ${ }^{3}$ and endoscopists by their knowledge of radiological findings when detecting gastric ulcers.

At least one physician from each of the three levels of cardiological training was influenced by knowledge of his interpretation of the enzyme concentrations, but only when this interpretation had been positive. The lack of influence of negative interpretations may have been because the doctors were practising a diagnostic strategy aimed at reducing the risk of overlooking an acute myocardial infarction.

Apparently, the final decision as to whether a patient has an acute myocardial infarction is not always reached by an independent interpretation of the electrocardiogram. As no true arbiter of acute myocardial infarction is available clinically we could not evaluate whether the influence of knowledge of enzyme concentrations resulted in more correct interpretations of the electrocardiogram. It should be noted, however, that in controlled clinical trials preconception is regarded as inappropriate and is minimised through blinding of the patient and the investigator.

Other members of the study group were: Jan Aagaard, Bo Jacobsen, Jørgen Linde, Johan Iversen, Ole Pedersen-Bjergaard, and Verner Rasmussen. We thank Miss Anette Larsen for secretarial help.

1 Hanson NR. Perception and discovery. An introduction to scientific inquiry. San Francisco: Freeman, Cooper \& $\mathrm{Co}, 1969$.

2 Johnson ML. Observer error. Its bearing on teaching. Lancet 1985;ii:422-4.

3 Gjørup T, Saurbrey N, Hermann N. Clinical estimation of the duration of pregnancy in legal abortion-are doctors biased by their knowledge of the duration of amenorrhoca? Methods Inf Med 1984;23:96-8.

4 Gjørup T, Agner E, Jensen LB, Jensen AM, Møllman K-M. The endoscopic diagnosis of gastric ulcer: a randomized clinical trial of observer variation and bias induced by knowledge of the radiological diagnosis. Scand f Gastroenterol 1985;20:554-8.

Accepted 22 October 1985

Department of Clinical Physiology and Nuclear Medicine, Herlev Hospital, University of Copenhagen, DK-2730 Herlev, Denmark

THOMAS GJØRUP, MD, registrar

HENNING KELBAEK, MD, registrar

LARS STENBYGARD, medical studen

FLEMMING SØRENSEN, medical student

Department of Medicine C and F, Herlev Hospital

JOHN GODTFREDSEN, MD, consultant

Statistical Research Unit, University of Copenhagen, DK-2100 Copenhagen $\emptyset$, Denmark

ANDERS MØRUP JENSEN, MSC, statistician

Correspondence and requests for reprints to: Dr Gjørup.

Agreement between positive and negative interpretations of enzyme concentrations and electrocardiograms (ECG) in patients with suspected acute myocardial infarction. (Figures are numbers $(\%)$ of patients)

\begin{tabular}{|c|c|c|c|c|c|}
\hline \multirow[b]{2}{*}{ Doctor ${ }^{*}$} & \multirow[b]{2}{*}{ Interpretation of ECG } & \multicolumn{2}{|c|}{$\begin{array}{l}\text { Patients whose enzyme concentrations } \\
\text { were interpreted as positive }\end{array}$} & \multicolumn{2}{|c|}{$\begin{array}{l}\text { Patients whose enzyme concentrations } \\
\text { were interpreted as negative }\end{array}$} \\
\hline & & $\begin{array}{l}\text { ECG interpreted with } \\
\text { knowledge of enzymes } \\
\text { (group 1, positive) }\end{array}$ & $\begin{array}{l}\text { ECG interpreted with- } \\
\text { out knowledge of enzymes } \\
\text { (group 2, positive) }\end{array}$ & $\begin{array}{l}\text { ECG interpreted with } \\
\text { knowledge of enzymes } \\
\text { (group 1, negative) }\end{array}$ & $\begin{array}{l}\text { ECG interpreted with- } \\
\text { out knowledge of enzymes } \\
\text { (group 2, negative) }\end{array}$ \\
\hline \multirow{2}{*}{ A } & Positive & $43(91)$ & $27(56) \mathrm{p}<0.0001$ & $6(10)$ & 10 (17) NS \\
\hline & Negative & $+(9)$ & $21(44)$ & $54(90)$ & $50(83)$ \\
\hline \multirow{2}{*}{ B } & Positive & $36(62)$ & 31 (55) NS & $10(20)$ & 13 (25) NS \\
\hline & Negative & $21(38)$ & $25(45)$ & $40(80)$ & $39(75)$ \\
\hline \multirow{2}{*}{ C } & Positive & $38(84)$ & $29(59) \mathrm{p}=0.01$ & $15(24)$ & 15 (25) NS \\
\hline & Negative & $7(16)$ & $20(41)$ & $47(76)$ & $44(75)$ \\
\hline \multirow{2}{*}{$\mathrm{D}$} & Positive & $29(83)$ & $22(54) \mathrm{p}=0.008$ & $12(17)$ & 7 (10) NS \\
\hline & Negative & $6(17)$ & $19(46)$ & $60(83)$ & $60(90)$ \\
\hline \multirow{2}{*}{ E } & Positive & $37(79)$ & $23(55) \mathrm{p}<0.0001$ & $11(18)$ & 7 (13) NS \\
\hline & Negative & $10(21)$ & $29(45)$ & $49(82)$ & $49(87)$ \\
\hline \multirow{2}{*}{$\mathrm{F}$} & Positive & $34(79)$ & 29 (66) NS & $21(33)$ & 18 (28) NS \\
\hline & Negative & $9(21)$ & $15(34)$ & $43(67)$ & $46(72)$ \\
\hline
\end{tabular}

"Doctors $\mathrm{A}$ and $\mathrm{B}$ were specialists in cardiology, $\mathrm{C}$ and $\mathrm{D}$ specialists in internal medicine, and $\mathrm{E}$ and $\mathrm{F}$ trainees in internal medicine. 